\title{
傾斜円柱回りの高分子溶液の流れの数值解析
}

\author{
（第 1 報）円柱回りの流机場
}

$\begin{array}{ccccc}\text { 大阪大学工学部 } & \text { 千 } & \text { 葉 } & \text { 訓 } & \text { 司 (会員) } \\ " \text { " } & \text { 菅 } & \text { 公 } & \text { 一 } & \text { 郎 } \\ " \text { " } & \text { 宋 } & & \text { 起 } & \text { 元 (") } \\ \text { " } & \text { 堀 } & & & \text { 明 (") }\end{array}$

\section{Numerical Solution for the Flow of Polymer Solutions Around an Inclined Circular Cylinder. Part 1 : The Flow Around a Circular Cylinder}

\author{
Kunji Chiba, Koichiro Kan, Ki-Won Song and Akira Horikawa \\ Department of Mechanical Engineering, Osaka University, Suita, Osaka
}

\begin{abstract}
Finite difference solutions for the time dependent equations of motion have been carried out in order to investigate the influence of shear thinning viscosity on the flow around an inclined cylinder of finite length in a uniform flow. In this numerical analysis the Cross model has been used.

The local flow over the cylinder is only slightly slant. However, in the wake flow behind the cylinder the particle path is remarkably influenced by the axial flow and rapidly flows up along the cylinder's axis. Then it gradually approaches the incoming flow direction. It has been found that non-Newtonian fluids are prone to flow axially in the vicinity of the cylinder.

These results obtained by the numerical analysis show a similar tendency to the flow visualization results. Thus, the present numerical analysis is valid to analyze the flow past an inclined cylinder.

The numerical solutions also demonstrate that for non-Newtonian fluids the length of the wake flow behind the cylinder with smaller diameter becomes larger at the same Reynolds number.

(Received July 7, 1984)

摘

\section{要}

一様流れ中に傾けておかれた有限長円柱周辺の流れを, Cross モデルを用いて数値解析により求め, 流体の持つ非二ュ一 トン粘性（Shear thinning viscosity）が流れに及ぼす影響を調べた。得られた結果はつぎのとおりである.

（1）流跡は，円柱後方に回り込んだ後，円柱から離れる際円柱軸方向に鋭く立上がること，および非ニュートン流体の埸 合の方が円柱近傍で軸方向に沿って流れやすいことが明らかになった。この傾向は，流れの可視化実験から得られた結 果と一致する．従って，ここで用いた計算方法は，傾斜门柱周辺の流れを表わすのに有効である.

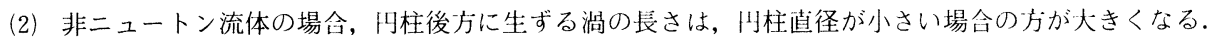

(昭利 59 年 7 月 7 日受理) 


\section{1. まえがき}

静止流体中で線状体（長さと直径の比が大きいま っすぐな円柱）を自由落下させると，ニュートン流 体中では線状体は水平な姿勢をとる向きに回転し， 最終的に水平姿勢を保ったまま落下する1)(図 1 (a)). ところが，非ニュートン粘性 (shear thinning viscosity）を有する高分子溶液中では線状体は鉛 直な姿勢をとる向きに回転する（図 1 (b))．さらに， 高分子溶液の非ニュートン性の度合が小さい場合, 線状体はある角度まで回転した後，その姿勢を保っ たまま並進運動する2).

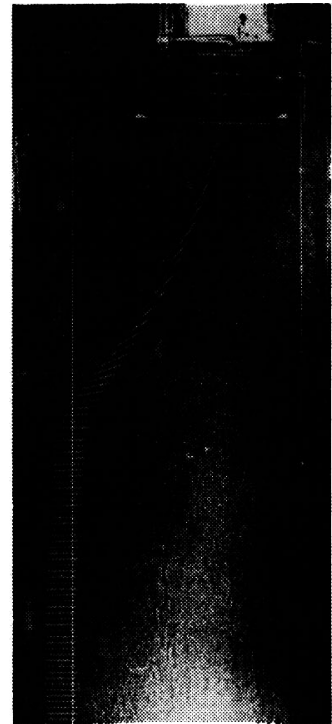

(a) in Water

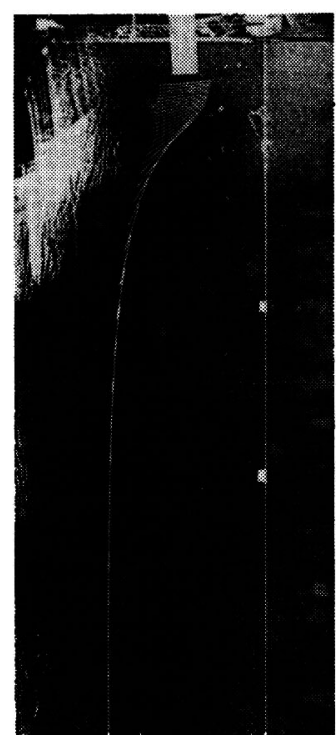

(b) in $0.25 w t \%$ PAA Solution
図 1 線状体のマルチストロボ写真

また, 絨維を分散させた高分子溶液が 2 次元の平 行平板流路内を流れる際, 溶液の非ニュートン性の 度合が大きいほど繊維は流れ方向に配向しやすいこ とがわかっている3).これらの現象は，高分子溶液 が有する非ニュートン粘性と大きく関係していると 考えられる。しかし，現段階では明確でないので， 線状体回りの流速場, 応力場の厳密な検討がこの現 象を解明するかぎになる.

そこで，本研究では，ニュートン流体および非二 ュートン流体の一様流れ中に傾けておかれた有限長 円柱に㗢く流体力とその周辺における流れ状態を数 值解析により求め, 非ニュートン粘性が流れ場や流 体力に与える影響を明らかにする．また，色素流脈 法による流れの可視化実験から得られた結果と数值 解析結果を比較し，数値解析の妥当性を検討する.
流れに直角におかれた円柱回りの 2 次元の流れ場 に関しては, ニュートン流体の場合, Thom ${ }^{4)}$ がレ イノルズ数 $R_{e}=10$ で初めて数值解を求めて以来数

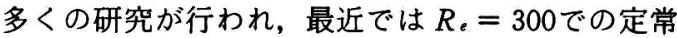
流れ場が得られている5).6. また，粘弾性流体の場 合には流れ状態のメカニズムが定性的ではあるが 徐々に解明されつつあるがまだ不明な点が多い7 99. 特に Mashelkar ら¹は，円柱前縁領域で形成される 境界層（弾性境界層と呼んでおり，法線忘力により 支配される) の概念を用いて粘弾性流体の流れのメ カニズムを説明している.

一方, ニュートン流体の一様流れ中に傾けておか れた有限長円柱周辺の流れについては, Slaouti ら ${ }^{10)}$ (円柱の長さと直径の比 $l / d=25 \sim 30, R_{e}=$ $60 \sim 200)$ ऐ Ramberg ${ }^{11)}\left(l / d=20 \sim 100, R_{e}=\right.$ 160１100）が, 円柱端部が円柱後方の伴流に及ぼ す影響を流れの可視化実験により調へ，端部の状態 が円柱軸方向のかなりの領域で伴流に影響を及ぼす ことを明らかにしている。しかし，流れ場を定量的 に調べた研究は見当らない。

本報では，傾斜円柱周辺の流れに対する数值解析 結果と流れの可視化実験から得られた結果を比較し ながら，非ニュートン粘性が流れ場に及ぼす影響を 明らかにする.

\section{2. 流速場, 応力場の数值解析}

\section{1 基硓式}

非圧縮性の連続体の運動は, 次式で表わされる. 連続の式

$v^{t},{ }_{i}=0$

コーシーの運動方程式

$\rho D v^{i} / D t=-p, g^{i \nu}+T^{u}$,

ここで， $v^{i}$ は流速ベクトル， $T^{i j}$ は偏差応力テンソ ル, 一 $p$ は応カテンソルの等方成分, $g^{i j}$ は計量テ ンソル, $\rho$ は密度, $t$ は時間, $D / D t$ は実質微分

$D v^{t} / D t=\partial v^{i} / \partial t+v_{, j}^{t} v^{j}$

である。

ここでは, 非ニュートン粘性の影響を調べること を目的としているので，解析に用いる構成式は，剪 断速度の広い領域で高分子溶液の粘度変化を良く表 わすCross モデル12)（図 9 参照, 図中の曲線は Cross モデルから求めたもので, 測定值と良く一致 している.）を 3 次元に拡張した式とする，従って， 
偏差応力テンソル $T^{\imath}$, は,

$T_{j}^{i}=2\left[\eta_{\infty}+\left(\eta_{0}-\eta_{\infty}\right) /\left\{1+\chi(4|\Pi e|)^{1 / 3}\right\}\right] e_{j}^{i}$

となる.ここで, $\eta_{0}$ はゼ口剪断粘度, $\eta_{\infty}$ は剪断速 度 $\rightarrow \infty$ での粘度, $x$ は物質パラメー夕, $e^{i}$,は才イ ラーの変形速度テンソル, II $e$ は $e^{i}$, の第 2 不変量 である。

傾斜円柱の形状之座標系を図 2 に示す。近寄り速 度 $U_{\infty}$ の方向を $y^{2}$ 方向とするとき, その軸が $y^{2} y^{3}$ 平 面内にあり，しかも $y^{2}$ 軸に対し角度 $\alpha$ だけ傾斜し ている円柱座標系 $(r, \theta, z)$ を用いる.ただし， $a$ は円柱半径, lは円柱長さである。

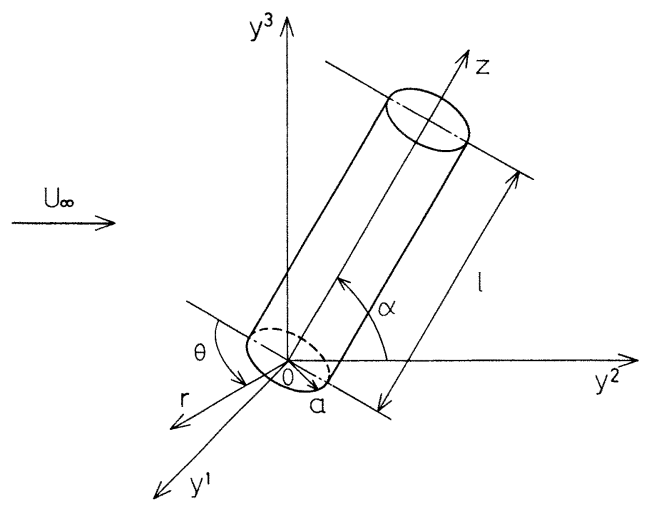

図 2 円柱形状と座標系

(1)，(2)，(4)式中のすべてのベクトル量とテンソル 量を $(r, \theta, z)$ 座標系で書き改める.つぎに(2)式 から $p$ を消去して渦度移動方程式を求めるが，流れ 関数は一般の 3 次元流れに対して, そのままでは存 在しない. そこで, ベクトル場に対し流速が $v=$ $\operatorname{curl} \boldsymbol{\phi}$ から求まるベクトルポテンシャル $\boldsymbol{\phi}$ を導入 する． $\phi$ は連続の式を満足する．また， $\omega$ を渦度べ クトルとする. 従って, つぎの量を用いて渦度移動 方程式を無次元化表示する.

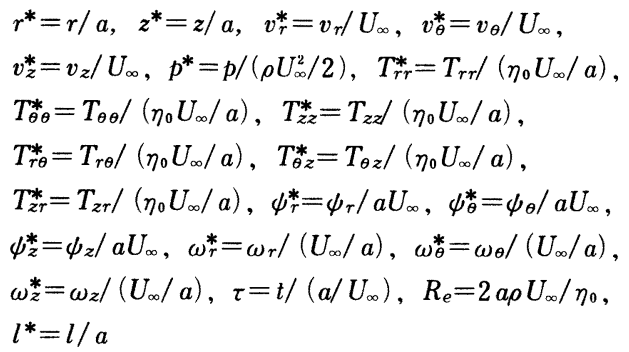

ただし，Vr， $T_{r}$ なよ゙は物理成分を表わし，Reはレ イノルズ数である。ささに，円柱表面近くで格子を 細かくとるのが望ましいので, つぎのような変数変 換を行うと, $r^{*}=e^{\pi \xi}, \eta=\theta / \pi, \zeta=z^{*}$

渦度移動方程式は次式となる。

$E^{2} \partial \omega_{r}^{*} / \partial \tau+\left(\partial \psi_{z}^{*} / \partial \eta-E \partial \psi_{\theta}^{*} / \partial \zeta\right) \partial \omega_{r}^{*} / \partial \xi$ $+\left(E \partial \psi_{r}^{*} / \partial \zeta-\partial \psi_{z}^{*} / \partial \xi\right) \partial \omega_{r}^{*} / \partial \eta+E\left(\partial \psi_{\theta}^{*} / \partial \xi\right.$ $\left.+\pi \psi_{\theta}^{*}-\partial \psi_{r}^{*} / \partial \eta\right) \partial \omega_{r}^{*} / \partial \zeta-\omega_{r}^{*}\left(\partial^{2} \psi_{z}^{*} / \partial \xi \partial \eta\right.$ $\left.-\pi \partial \psi_{z}^{*} / \partial \eta-E \partial^{2} \psi_{\theta}^{*} / \partial \zeta \partial \xi\right)-\omega_{\theta}^{*}\left(\partial^{2} \psi_{z}^{*} / \partial \eta^{2}\right.$ $\left.-E \partial^{2} \psi_{\theta}^{*} / \partial \eta \partial \zeta\right)-E \omega_{z}^{*}\left(\partial^{2} \psi_{z}^{*} / \partial \eta \partial \zeta-E \partial^{2} \psi_{\theta}^{*} / \partial \zeta^{2}\right)$ $=\left(2 / R_{e}\right)\left[\Theta^{*}\left(\Delta \omega_{r}^{*}-2 \pi \partial \omega_{\theta}^{*} / \partial \eta-\pi^{2} \omega_{r}^{*}\right)+\partial \Theta^{*} / \partial \xi\right.$ $\left\{\partial \omega_{r}^{*} / \partial \xi+\pi \omega_{r}^{*}+(2 \pi / E)\left(E \partial^{2} \psi_{r}^{*} / \partial \zeta^{2}-\partial^{2} \psi_{z}^{*} / \partial \zeta \partial \xi\right)\right\}$ $+\partial \Theta^{*} / \partial \eta\left\{2 \partial \omega_{r}^{*} / \partial \eta-\partial \omega_{\theta}^{*} / \partial \xi-\pi \omega_{\theta}^{*}-(2 \pi / E)\right.$ $\left.\left(\partial^{2} \psi_{z}^{*} / \partial \eta \partial \zeta-E \partial^{2} \psi_{\theta}^{*} / \partial \zeta^{2}\right)\right\}+E \partial \Theta^{*} / \partial \zeta\left(2 E \partial \omega_{r}^{*} / \partial \zeta\right.$ $\left.\left.-\partial \omega_{z}^{*} / \partial \xi\right)+\partial^{2} \Theta^{*} / \partial \eta^{2}\right\} \omega_{r}^{*}+(2 / E)\left(E \partial^{2} \psi_{r}^{*} / \partial \zeta^{2}\right.$ $\left.\left.-\partial^{2} \psi_{z}^{*} / \partial \zeta \partial \xi\right)\right\}-E^{2} \partial^{2} \Theta^{*} / \partial \zeta^{2}\left\{\omega_{r}^{*}+(2 / E)\left(E \partial^{2} \psi_{r}^{*} / \partial \zeta^{2}\right.\right.$ $\left.\left.-\partial^{2} \psi_{z}^{*} / \partial \zeta \partial \xi\right)\right\}+\partial^{2} \Theta^{*} / \partial \xi \partial \eta\left\{-\omega_{\theta}^{*}+(2 / E)\right.$ $\left.\left.\left(\partial^{2} \psi_{z}^{*} / \partial \eta \partial \zeta-E \partial^{2} \psi_{\theta}^{*} / \partial \zeta^{2}\right)\right\}+\partial^{2} \Theta^{*} / \partial \eta \partial \zeta\right\}(2 / E)$ $\left(\partial^{2} \psi_{z}^{*} / \partial \xi \partial \eta-\pi \partial \psi_{z}^{*} / \partial \eta+E \partial^{2} \psi_{\theta}^{*} / \partial \zeta \partial \xi\right)+4\left(\pi \partial \psi_{\theta}^{*} / \partial \zeta\right.$ $\left.\left.-\partial^{2} \psi_{r}^{*} / \partial \eta \partial \zeta\right)\right\}+\partial^{2} \Theta^{*} / \partial \zeta \partial \xi\left\{E \omega_{z}^{*}-(2 / E)\right.$

$\left.\left.\left(E \partial^{2} \psi_{r}^{*} / \partial \zeta \partial \xi+\pi \partial \psi_{z}^{*} / \partial \xi-\partial^{2} \psi_{z}^{*} / \partial \xi^{2}\right)\right\}\right]$

$E^{2} \partial \omega_{\theta}^{*} / \partial \tau+\left(\partial \psi_{z}^{*} / \partial \eta-E \partial \psi_{\theta}^{*} / \partial \zeta\right)\left(\partial \omega_{\theta}^{*} / \partial \xi-\pi \omega_{\theta}^{*}\right)$

$+\left(E \partial \psi_{r}^{*} / \partial \zeta-\partial \psi_{z}^{*} / \partial \xi\right) \partial \omega_{\theta}^{*} / \partial \eta+E\left(\partial \psi_{\theta}^{*} / \partial \xi+\pi \psi_{\theta}^{*}\right.$

$\left.-\partial \psi_{r}^{*} / \partial \eta\right) \partial \omega_{\theta}^{*} / \partial \zeta-\omega_{r}^{*}\left\{E\left(\partial^{2} \psi_{r}^{*} / \partial \zeta \partial \xi-\pi \partial \psi_{r}^{*} / \partial \zeta\right)\right.$

$\left.-\left(\partial^{2} \psi_{z}^{*} / \partial \xi^{2}-2 \pi \partial \psi_{z}^{*} / \partial \xi\right)\right\}-\omega_{\theta}^{*}\left(E \partial^{2} \psi_{r}^{*} / \partial \eta \partial \zeta\right.$

$\left.-\partial^{2} \psi_{z}^{*} / \partial \xi \partial \eta\right)-E \omega_{z}^{*}\left(E \partial^{2} \psi_{r}^{*} / \partial \zeta^{2}-\partial^{2} \psi_{z}^{*} / \partial \zeta \partial \xi\right)$

$=\left(2 / R_{e}\right)\left[\Theta^{*}\left(\Delta \omega_{\theta}^{*}+2 \pi \partial \omega_{r}^{*} / \partial \eta-\pi^{2} \omega_{\theta}^{*}\right)+\partial \Theta^{*} / \partial \xi\right.$

$\left\{2 \partial \omega_{\theta}^{*} / \partial \xi-\partial \omega_{r}^{*} / \partial \eta+(2 \pi / E)\left(\partial^{2} \psi_{z}^{*} / \partial \eta \partial \zeta\right.\right.$

$\left.\left.-E \partial^{2} \psi_{\theta}^{*} / \partial \zeta^{2}\right)\right\}+\partial \Theta^{*} / \partial \eta\left\{\partial \omega_{\theta}^{*} / \partial \eta+2 \pi \omega_{r}^{*}+(2 \pi / E)\right.$

$\left.\left(E \partial^{2} \psi_{r}^{*} / \partial \zeta^{2}-\partial^{2} \psi_{z}^{*} / \partial \zeta \partial \xi\right)\right\}+E \partial \Theta^{*} / \partial \zeta\left(2 E \partial \omega_{\theta}^{*} / \partial \zeta\right.$

$\left.-\partial \omega_{z}^{*} / \partial \eta\right)+\partial^{2} \Theta^{*} / \partial \xi^{2}\left\{\omega_{\theta}^{*}+(2 / E)\left(E \partial^{2} \psi_{\theta}^{*} / \partial \zeta^{2}\right.\right.$

$\left.\left.-\partial^{2} \psi_{z}^{*} / \partial \eta \partial \zeta\right)\right\}-E^{2} \partial^{2} \Theta^{*} / \partial \zeta^{2}\left\{\omega_{\theta}^{*}+(2 / E)\left(E \partial^{2} \psi_{\theta}^{*} / \partial \zeta^{2}\right.\right.$

$\left.\left.-\partial^{2} \psi_{z}^{*} / \partial \eta \partial \zeta\right)\right\}+\partial^{2} \Theta^{*} / \partial \xi \partial \eta\left\{-\omega_{r}^{*}+(2 / E)\left(\partial^{2} \psi_{z}^{*} / \partial \zeta \partial \xi\right.\right.$

$\left.\left.\left.-E \partial^{2} \phi_{r}^{*} / \partial \zeta^{2}\right)\right\}+\partial^{2} \Theta^{*} / \partial \eta \partial \zeta\right\}-E \omega_{z}^{*}+(2 / E)$

$\left.\left(E \partial^{2} \psi_{r}^{*} / \partial \zeta \partial \xi-\partial^{2} \psi_{z}^{*} / \partial \xi^{2}+\pi \partial \psi_{z}^{*} / \partial \xi\right)\right\}+\partial^{2} \Theta^{*} / \partial \zeta \partial \xi$

$\left\{(2 / E)\left(\partial^{2} \psi_{z}^{*} / \partial \xi \partial \eta-\pi \partial \psi_{z}^{*} / \partial \eta-2 E \partial^{2} \psi_{\theta}^{*} / \partial \zeta \partial \xi\right.\right.$

$\left.\left.\left.-\pi E \partial \psi_{\theta}^{*} / \partial \zeta+E \partial^{2} \psi_{r}^{*} / \partial \eta \partial \zeta\right)\right\}\right]$

$E^{2} \partial \omega_{z}^{*} / \partial \tau+\left(\partial \psi_{z}^{*} / \partial \eta-E \partial \psi_{\theta}^{*} / \partial \zeta\right) \partial \omega_{z}^{*} / \partial \xi$

$+\left(E \partial \psi_{r}^{*} / \partial \zeta-\partial \psi_{z}^{*} / \partial \xi\right) \partial \omega_{z}^{*} / \partial \eta+E\left(\partial \psi_{\theta}^{*} / \partial \xi\right.$

$\left.+\pi \psi_{\theta}^{*}-\partial \psi_{r}^{*} / \partial \eta\right) \partial \omega_{z}^{*} / \partial \zeta-\omega_{r}^{*}\left(\partial^{2} \psi_{\theta}^{*} / \partial \xi^{2}\right.$

$\left.-\partial^{2} \psi_{r}^{*} / \partial \xi \partial \eta+\pi \partial \psi_{r}^{*} / \partial \eta-\pi^{2} \psi_{\theta}^{*}\right)-\omega_{\theta}^{*}\left(\partial^{2} \psi_{\theta}^{*} / \partial \xi \partial \eta\right.$

$\left.+\pi \partial \psi_{\theta}^{*} / \partial \eta-\partial^{2} \psi_{r}^{*} / \partial \eta^{2}\right)-E \omega_{z}^{*}\left(\partial^{2} \psi_{\theta}^{*} / \partial \zeta \partial \xi\right.$

$\left.+\pi \partial \psi_{\theta}^{*} / \partial \zeta-\partial^{2} \psi_{r}^{*} / \partial \eta \partial \zeta\right)=\left(2 / R_{e}\right)\left[\Theta^{*}\left(\Delta \omega_{z}^{*}\right)\right.$

$+\partial \Theta^{*} / \partial \xi\left\{2 \partial \omega_{z}^{*} / \partial \xi-E \partial \omega_{r}^{*} / \partial \zeta+2 \pi \omega_{z}^{*}-\left(4 \pi / E^{2}\right)\right.$

$\left.\left(E \partial^{2} \psi_{r}^{*} / \partial \zeta \partial \xi-\partial^{2} \psi_{z}^{*} / \partial \xi^{2}+\pi \partial \psi_{z}^{*} / \partial \xi\right)\right\}$

$+\partial \Theta^{*} / \partial \eta\left\{2 \partial \omega_{z}^{*} / \partial \eta-E \partial \omega_{\theta}^{*} / \partial \zeta+\left(4 \pi / E^{2}\right)\right.$

$\left(\partial^{2} \psi_{z}^{*} / \partial \xi \partial \eta-\pi \partial \psi_{z}^{*} / \partial \eta\right)-(2 \pi / E)\left(\partial^{2} \psi_{\theta}^{*} / \partial \zeta \partial \xi\right.$ 
$\left.\left.-\pi \partial \psi_{\theta}^{*} / \partial \zeta+\partial^{2} \psi_{r}^{*} / \partial \eta \partial \zeta\right)\right\}+\partial \Theta^{*} / \partial \zeta\left(E^{2} \partial \omega_{z}^{*} / \partial \zeta\right)$

$-\partial^{2} \underline{\Theta}^{*} / \partial \xi^{2}\left\{\omega_{z}^{*}+\left(2 / E^{2}\right)\left(\partial^{2} \psi_{z}^{*} / \partial \xi^{2}-\pi \partial \psi_{z}^{*} / \partial \xi\right.\right.$

$\left.\left.-E \partial^{2} \psi_{r}^{*} / \partial \zeta \partial \xi\right)\right\}+\partial^{2} \Theta^{*} / \partial \eta^{2}\left\{\omega_{z}^{*}+\left(2 / E^{2}\right)\right.$

$\left.\left(\partial^{2} \psi_{z}^{*} / \partial \xi^{2}-\pi \partial \psi_{z}^{*} / \partial \xi-E \partial^{2} \psi_{r}^{*} / \partial \zeta \partial \xi\right)\right\}$

$+\partial^{2} \Theta^{*} / \partial \xi \partial \eta\left\{(2 / E)\left(\partial^{2} \psi_{\theta}^{*} / \partial \zeta \partial \xi-\pi \partial \psi_{\theta}^{*} / \partial \zeta\right.\right.$

$\left.\left.+\partial^{2} \psi_{r}^{*} / \partial \eta \partial \zeta\right)-\left(4 / E^{2}\right)\left(\partial^{2} \psi_{z}^{*} / \partial \xi \partial \eta-\pi \partial \psi_{z}^{*} / \partial \eta\right)\right\}$

$+\partial^{2} \Theta * / \partial \eta \partial \zeta\left\{E \omega_{\theta}^{*}+2\left(E \partial^{2} \psi_{\theta}^{*} / \partial \zeta^{2}-\partial^{2} \psi_{z}^{*} / \partial \eta \partial \zeta\right)\right\}$

$\left.+\partial^{2} \Theta^{*} / \partial \zeta \partial \xi\left\{E \omega_{r}^{*}+2\left(E \partial^{2} \psi_{r}^{*} / \partial \zeta^{2}-\partial^{2} \psi_{z}^{*} / \partial \zeta \partial \xi\right)\right\}\right)$

ただし， $E=\pi e^{\pi \xi}, \Delta=\partial^{2} / \partial \xi^{2}+\partial^{2} / \partial \eta^{2}+E^{2} \partial^{2} / \partial \zeta^{2}$ であ

る.また, $\theta^{*}$ は無次元化粘度で

$$
\begin{aligned}
\Theta^{*}=\Theta / \eta_{0} & =\eta_{\infty} / \eta_{0}+\left(1-\eta_{\infty} / \eta_{0}\right) /\left[1+\chi(4|\Pi e|)^{1 / 3}\right] \\
& =\eta_{\infty}^{*}+\left(1-\eta_{\infty}^{*}\right) /\left[1+\varkappa(4|\Pi e|)^{1 / 3}\right] \quad \cdots \cdots(10)
\end{aligned}
$$

である.ここで,

$4|\Pi e|=\left(U_{\infty} / a E\right)^{2}[2\}\left(\partial v_{r}^{*} / \partial \xi\right)^{2}+\left(\partial v_{\theta}^{*} / \partial \eta+\pi v_{r}^{*}\right)^{2}$

$$
\begin{aligned}
& \left.+\left(E \partial v_{z}^{*} / \partial \zeta\right)^{2}\right\}+\left(\partial v_{\theta}^{*} / \partial \xi-\pi v_{\theta}^{*}+\partial v_{r}^{*} / \partial \eta\right)^{2} \\
& +\left(E \partial v_{\theta}^{*} / \partial \zeta+\partial v_{z}^{*} / \partial \eta\right)^{2}+\left(E \partial v_{r}^{*} / \partial \zeta\right. \\
& \left.\left.+\partial v_{z}^{*} / \partial \xi\right)^{2}\right]
\end{aligned}
$$

となる。

さらに, $\boldsymbol{\phi}^{*}$ と $\omega^{*}$ の関係は次式で表わされる.

$\Delta \psi_{r}^{*}-2 \pi \partial \psi_{\theta}^{*} / \partial \eta-\pi^{2} \psi_{r}^{*}=-E^{2} \omega_{r}^{*}$

$\Delta \psi_{\theta}^{*}+2 \pi \partial \psi_{r}^{*} / \partial \eta-\pi^{2} \psi_{\theta}^{*}=-E^{2} \omega_{\theta}^{*} \quad \cdots \cdots \cdots \ldots \ldots \ldots \ldots \ldots \ldots \ldots(13)$

$\Delta \psi_{z}^{*} \quad=-E^{2} \omega_{z}^{*} \quad \cdots \cdots \cdots \cdots \cdots \cdots \cdots(14)$

また，応力の偏差成分は

$T_{r r}^{*}=2\left(\Theta^{*} / E\right) \partial v_{r}^{*} / \partial \xi$,

$T_{\theta \theta}^{*}=2\left(\Theta^{*} / E\right)\left(\partial v_{\theta}^{*} / \partial \eta+\pi v_{r}^{*}\right)$,

$T_{z z}^{*}=2 \Theta^{*} \partial v_{z}^{*} / \partial \zeta$,

$T_{r \theta}^{*}=\left(\Theta^{*} / E\right)\left(\partial v_{\theta}^{*} / \partial \xi-\pi v_{\theta}^{*}+\partial v_{r}^{*} / \partial \eta\right)$,

$T_{\theta z}^{*}=\left(\Theta^{*} / E\right)\left(E \partial v_{\theta}^{*} / \partial \zeta+\partial v_{z}^{*} / \partial \eta\right)$,

$T_{z r}^{*}=\left(\Theta^{*} / E\right)\left(\partial v_{z}^{*} / \partial \xi+E \partial v_{r}^{*} / \partial \zeta\right)$

となる。

境界条件は，無限遠方で一様流れであり，円柱面上 で流速 0 とする.

$\xi \rightarrow \infty$ および $\zeta \rightarrow \pm \infty て ゙$,

$v_{r}^{*}=-\sin \alpha \cos \pi \eta, v_{\theta}^{*}=\sin \alpha \sin \pi \eta, v_{z}^{*}=\cos \alpha$

(16a)

$\xi=0,0 \leqq \zeta \leqq l^{*}$ および $\xi<0, \zeta=0, l^{*}$ で,

$v_{r}^{*}=v_{\theta}^{*}=v_{z}^{*}=0$

$\eta=0,1$ で,

$\partial v_{r}^{*} / \partial \eta=\partial v_{z}^{*} / \partial \eta=v_{\theta}^{*}=0$

$(16 c)$

\section{2 数值計算の方法}

数值計算では，境界条件のもとで渦度移動方程式 (7) 〜 (9)式を ADI 法で， $\boldsymbol{\phi}^{*}$ と $\boldsymbol{\omega}^{*}$ の関係を表わす(12) 〜(14)式を SOR 法で解き, 非定常解を定常状態に近 づける.フローチャートを戍 3 に示す。

夕イムステップを $\Delta \tau$, その数を $n$ とすると, $\mathrm{ADI}$ 法では $\Delta \tau$ を 3 等分し, $\tau=(n+1 / 3) \Delta \tau, \tau$

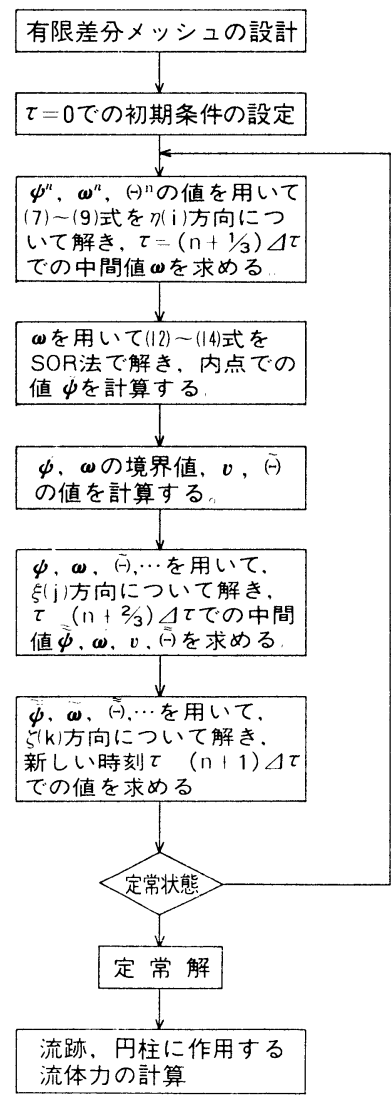

困 3 計算の手順

$=(n+2 / 3) \Delta \tau$ における中間値 算し，それらの值を用いて新しい時刻 $\tau=(n+$ 1) $\Delta \tau$ での值 $\boldsymbol{\omega}^{\mathrm{n}+1}$ を求める。 その際，基礎式の非 線形性が強いので， $\omega$ の中間值を計算した直後に(12) 〜(14)式を SOR 法で解き， $\boldsymbol{\phi}$ の中間値 $\widetilde{\boldsymbol{\phi}}, \widetilde{\widetilde{\phi}}$ を計算 し, それらの值を用いて順次該算を進めてゆく.こ の方法では, 線形化域を $\Delta \tau / 3$ ずつ動かしたこと になる。

$\eta, \xi, \zeta$ 方向の格子点を添字 $i, j, k$ で，また格 子間隔を $\Delta \eta, \Delta \xi, \Delta \zeta て ゙$ 表わすと，例えば，渦度移 動方程式の $\xi$ 方向成分 $(7)$ 式についてはつぎの $3 つ の$ 有限差分近似式が得られる.

$\left(3 E^{2} / \Delta \tau\right)\left(\widetilde{\omega}_{r, i, j, k}-\omega_{r, i, j, \kappa}^{n}\right)+\left(\delta \psi_{z}^{n} / \delta \eta-E \delta \psi_{\theta}^{n} / \delta \zeta\right)$ $\delta \omega_{r}^{n} / \delta \xi+\left(E \delta \psi_{r}^{n} / \delta \zeta-\delta \psi_{z}^{n} / \delta \xi\right)\left(\widetilde{\omega}_{r, i+1, j, k}-\widetilde{\omega}_{r, i-1, j, k}\right)$

$/ 2 \Delta \eta+E\left(\delta \psi_{\theta}^{n} / \delta \xi+\pi \psi_{\theta}-\delta \psi_{r}^{n} / \delta \eta\right) \delta \omega_{r}^{n} / \delta \zeta$

$-\omega_{r, i, j, k}^{n}\left(\delta^{2} \psi_{z}^{n} / \delta \xi \delta \eta-\pi \delta \psi_{z}^{n} / \delta \eta-E \delta^{2} \psi_{\theta}^{n} / \delta \zeta \delta \xi\right)$

$-\omega_{\theta, i, j, k}^{n}\left(\delta^{2} \psi_{z}^{n} / \delta \eta^{2}-E \delta^{2} \psi_{\theta}^{n} / \delta \eta \delta \zeta\right)-E \omega_{z, i, j, k}^{n}$

$\left(\delta^{2} \psi_{z}^{n} / \delta \eta \delta \zeta-E \delta^{2} \psi_{\theta}^{n} / \delta \zeta^{2}\right)$

$=\left(2 / R_{e}\right)\left[\Theta_{i, j, k}^{n}\left\{\delta^{2} \omega_{r}^{n} / \delta \xi^{2}+\left(\widetilde{\omega}_{r, i+1, j, k}-2 \widetilde{\omega}_{r, i, j, k}\right.\right.\right.$

$\left.+\widetilde{\omega}_{r, i-1, j, k}\right) /(\Delta \eta)^{2}+E^{2} \delta^{2} \omega_{r}^{n} / \delta \zeta^{2}-2 \pi\left(\widetilde{\omega}_{\theta, i+1, j, k}\right.$

$\left.\left.-\widetilde{\omega}_{\theta, i-1, j, k}\right) / 2 \Delta \eta-\pi^{2} \omega_{r, i, j, k}^{n}\right\}+\delta \Theta^{n} / \delta \xi\left\{\delta \omega_{r}^{n} / \delta \xi\right.$ 
$\left.+\pi \omega_{r, i, j, k}^{n}+(2 \pi / E)\left(E \delta^{2} \psi_{r}^{n} / \delta \zeta^{2}-\delta^{2} \psi_{z}^{n} / \delta \zeta \delta \xi\right)\right\}$

$+\partial \Theta^{n} / \delta \eta\left\{2\left(\widetilde{\omega}_{r, i+1, j, k}-\widetilde{\omega}_{r, i-1, j, k}\right) / 2 \Delta \eta-\delta \omega_{\theta}^{n} / \delta \xi\right.$

$\left.-\pi \omega_{\theta, i, j, k}^{n}-(2 \pi / E)\left(\delta^{2} \psi_{z}^{n} / \delta \eta \delta \zeta-E \delta^{2} \psi_{\theta}^{n} / \delta \zeta^{2}\right)\right\}$

$+E \partial \Theta^{n} / \delta \zeta\left(2 E \delta \omega_{r}^{n} / \delta \zeta-\delta \omega_{z}^{n} / \delta \xi\right)+$

$\left.f\left(\psi^{n}, \omega^{n}, \Theta^{n}\right)\right]$

$\left(3 E^{2} / \Delta \tau\right)\left(\widetilde{\omega}_{r, i, j, k}-\widetilde{\omega}_{r, i, j, k}\right)+\left(\delta \bar{\psi}_{z} / o \eta \eta-E \delta \widetilde{\psi}_{\theta} / \delta \zeta\right)$

$\left(\widetilde{\widetilde{\omega}}_{r, i, j+1, k}-\widetilde{\widetilde{\omega}}_{r, i, j-1, k}\right) / 2 \Delta \xi+\left(E \delta \widetilde{\psi}_{r} / \delta \zeta-\delta \widetilde{\psi}_{z} / \delta \xi\right)$

$\delta \widetilde{\omega}_{r} / \delta \eta+E\left(\delta \bar{\psi}_{\theta} / \delta \xi+\pi \bar{\psi}_{\theta}-\delta \widetilde{\psi}_{r} / \delta \eta\right) \delta \omega_{r}^{n} / \delta \zeta$

$-\widetilde{\omega}_{r, i, j, k}\left(\delta^{2} \widetilde{\psi}_{z} / \delta \xi \delta \eta-\pi \delta \widetilde{\psi}_{z} / \delta \eta-E \delta^{2} \widetilde{\psi}_{\theta} / \delta \zeta \delta \xi\right)$

$-\widetilde{\omega}_{\theta, i, j, k}\left(\delta^{2} \widetilde{\psi}_{z} / \delta \eta^{2}-E \delta^{2} \widetilde{\psi}_{\theta} / \delta \eta \delta \zeta\right)-E \widetilde{\omega}_{z, i, j, k}$

$\left(\delta^{2} \widetilde{\psi} z / \delta \eta \delta \zeta-E \delta^{2} \widetilde{\psi_{\theta}} / \delta \zeta^{2}\right)$

$\left.=(2 / \operatorname{Re})\left[\Theta_{i, j, k} \mid \widetilde{\widetilde{\omega}}_{r, i, j+1, k}-2 \widetilde{\widetilde{\omega}}_{r, i, j, k}+\widetilde{\widetilde{\omega}}_{r, i, j-1, k}\right)\right]$

$(\Delta \xi)^{2}+\delta^{2} \widetilde{\omega}_{r} / \delta \eta^{2}+E^{2} \delta^{2} \omega_{r}^{n} / \delta \zeta^{2}-2 \pi \delta \widetilde{\omega}_{\theta} / \delta \eta$

$\left.\left.-\pi^{2} \widetilde{\omega}_{r, i, j, k}\right\}+\delta \widetilde{\Theta} / \delta \xi\right\}\left(\widetilde{\widetilde{\omega}}_{r, i, j+1, k}-\widetilde{\widetilde{\omega}}_{r, i, j-1, k}\right) / 2 \Delta \xi$

$\left.+\pi \widetilde{\omega}_{r, i, k, k}+(2 \pi / E)\left(E \delta^{2} \widetilde{\psi}_{r} / \delta \zeta^{2}-\delta^{2} \widetilde{\psi}_{z} / \delta \zeta \delta \xi\right)\right\}$

$+\partial \widetilde{\Theta} / \delta \eta\left\{2 \delta \widetilde{\omega}_{r} / \delta \eta-\left(\widetilde{\omega}_{\theta, i, j+1, k}-\widetilde{\widetilde{\omega}}_{\theta, i, j-1, k}\right) / 2 \Delta \xi\right.$

$\left.-\pi \widetilde{\omega}_{\theta, i, k, k}-(2 \pi / E)\left(\delta^{2} \widetilde{\psi}_{z} / \delta \eta \delta \zeta-E \delta^{2} \widetilde{\psi}_{\theta} / \delta \zeta^{2}\right)\right\}$

$+E \delta \widetilde{\widetilde{\Theta}} / \delta \zeta\left\{2 E \partial \omega_{r}^{n} / \delta \zeta-\left(\widetilde{\omega}_{z, i, j+1, k}-\widetilde{\widetilde{\omega}}_{z, i, j-1, k}\right) / 2 \Delta \xi\right\}$

$+f(\overline{\boldsymbol{\psi}}, \widetilde{\boldsymbol{\omega}}, \widetilde{\boldsymbol{\theta}})]$

$\left(3 E^{2} / \Delta \tau\right)\left(\omega_{r, i, j, k}^{n+1}-\widetilde{\widetilde{\omega}}_{r, i, j, k}\right)+\left(\delta \widetilde{\widetilde{\psi}}_{z} / \delta \eta-E \delta \widetilde{\widetilde{\psi}}_{\theta} / \delta \zeta\right)$

$\delta \widetilde{\omega}_{r} / \delta \xi+\left(E \delta \widetilde{\bar{\psi}}_{r} / \delta \zeta-\delta \widetilde{\widetilde{\psi}}_{z} / \delta \xi\right) \delta \widetilde{\omega}_{r} / \delta \eta+E\left(\delta \widetilde{\bar{\psi}}_{\theta} / \delta \xi\right.$

$\left.+\pi \psi_{\theta}-\delta \widetilde{\bar{\psi}}_{r} / \delta \eta\right)\left(\omega_{r, i, j, k+1}^{n+1}-\omega_{r, i, j, k-1}^{n+1}\right) / 2 \Delta \zeta-\widetilde{\widetilde{\omega}}_{r, i, j, k}$

$\left(\partial^{2} \widetilde{\bar{\psi}}_{z} / \delta \xi \delta \eta-\pi \delta \widetilde{\widetilde{\psi}}_{z} / \delta \eta-E \delta^{2} \widetilde{\widetilde{\psi}}_{\theta} / \delta \zeta \delta \xi\right)-\widetilde{\widetilde{\omega}}_{\theta i . i j . k}$

$\left(\delta^{2} \widetilde{\bar{\psi}}_{z} / \delta \eta^{2}-E \delta^{2} \widetilde{\widetilde{\psi}}_{\theta} / \delta \eta \delta \zeta\right)-E \widetilde{\widetilde{\omega}}_{z, i, j, k}\left(\delta^{2} \widetilde{\widetilde{\psi}}_{z} / \delta \eta \delta \zeta\right.$

$\left.-E \delta^{2} \widetilde{\bar{\psi}_{\theta}} / \delta \zeta^{2}\right)$

$=(2 / \operatorname{Re})\left[\widetilde{\widetilde{\Theta}}_{i, j, k}\right\} \delta^{2} \widetilde{\omega}_{r} / \delta \xi^{2}+\delta^{2} \widetilde{\omega}_{r} / \delta \eta^{2}+E^{2}\left(\omega_{r, i, j, k+1}^{n+1}\right.$

$\left.\left.-2 \omega_{r, i, j, k}^{n+1}+\omega_{r, i, j, k-1}^{n+1}\right) /(\Delta \zeta)^{2}-2 \pi \delta \widetilde{\omega}_{\theta} / \delta \eta-\pi^{2} \widetilde{\omega}_{r, i, j, k}\right\}$

$+\delta \widetilde{\widetilde{\Theta}} / \delta \delta \xi\} \delta \widetilde{\widetilde{\omega}}_{r} / \delta \xi+\pi \widetilde{\widetilde{\omega}}_{r, i, j, k}+(2 \pi / E)\left(E \delta^{2} \widetilde{\widetilde{\psi}}_{r} / \delta \zeta^{2}\right.$

$\left.\left.-\delta^{2} \widetilde{\bar{\psi}}_{z} / \delta \zeta \delta \xi\right)\right\}+\delta \widetilde{\widetilde{\Theta}} / \delta \eta\left\{2 \delta \widetilde{\omega}_{r} / \delta \eta-\delta \widetilde{\widetilde{\omega}}_{\theta} / \delta \xi-\right.$

$\left.-\pi \widetilde{\widetilde{\omega}}_{\theta, i, k, k}-(2 \pi / E)\left(\delta^{2} \widetilde{\bar{\psi}}_{z} / \delta \eta \delta \zeta-E \delta^{2} \widetilde{\bar{\psi}_{\theta}} / \delta \zeta^{2}\right)\right\}$

$+E \delta \widetilde{\widetilde{\Theta}} / \delta \zeta\left\{2 E\left(\omega_{r, i, j, k+1}^{n+1}-\omega_{r, i, j, k-1}^{n+1}\right) / 2 \Delta \zeta-\delta \widetilde{\widetilde{\omega}}_{z} / \delta \xi\right\}$

$+f(\widetilde{\widetilde{\boldsymbol{\Psi}}}, \widetilde{\boldsymbol{\omega}}, \widetilde{\widetilde{\Theta}})]$

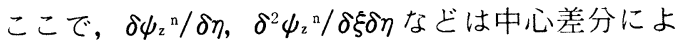

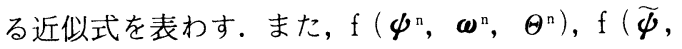
$\widetilde{\boldsymbol{\omega}}, \Theta)$ およびf $(\widetilde{\widetilde{\boldsymbol{\varphi}}}, \widetilde{\boldsymbol{\omega}}, \Theta)$ は, (7)式の右辺の $\Theta^{*}$ の 2 次導関数に関する項の差分近似式を表わし ており, 例えば,

$f\left(\boldsymbol{\psi}^{n}, \boldsymbol{\omega}^{n}, \Theta^{n}\right)=$

$\delta^{2} \Theta^{n} / \delta \eta^{2}\left\{\omega_{r}^{n}+(2 / E)\left(E \delta^{2} \psi_{r}^{n} / \delta \zeta^{2}-\delta^{2} \psi_{z}^{n} / \delta \zeta \delta \xi\right)\right\}-$

$\left.\left.E^{2} \delta^{2} \theta^{n} / \delta \zeta^{2}\right\} \omega_{r}^{n}+(2 / E)\left(E \delta^{2} \psi_{r}^{n} / \delta \zeta^{2}-\delta^{2} \psi_{z}^{n} / \delta \zeta \delta \xi\right)\right\}$

$+\partial^{2} \Theta^{n} / \delta \xi \delta \eta \eta-\omega_{\theta}^{n}+(2 / E)\left(\delta^{2} \psi_{z}^{n} / \delta \eta \delta \zeta\right.$

$\left.\left.-E \delta^{2} \psi_{\theta}^{n} / \delta \zeta^{2}\right)\right\}+\delta^{2} \Theta^{n} / \delta \eta \delta \zeta(2 / E)\left(\delta^{2} \psi_{z}^{n} / \delta \xi \delta \eta\right.$

$\left.-\pi \delta \psi_{z}^{n} / \delta \eta+E \delta^{2} \psi_{\theta}^{n} / \delta \zeta \delta \xi\right)+4\left(\pi \delta \psi_{\theta}^{n} / \delta \zeta\right.$

$\left.\left.-\delta^{2} \psi_{r}^{n} / \delta \eta \delta \zeta\right)\right\}+\delta^{2} \Theta^{n} / \delta \zeta \delta \xi \xi E \omega_{z}^{n}-(2 / E)$

$\left.\left(E \delta^{2} \psi_{r}^{n} / \delta \zeta \delta \xi+\pi \delta \psi_{z}^{n} / \delta \xi-\delta^{2} \psi_{z}^{n} / \delta \xi^{2}\right)\right\}$
図 4 に円柱中央部（ $\zeta=20 ）$ の表面における渦度 の発達状態を示す. 初期条件は一様流れである. 図 4 (b)から, 定常な流れ場に近づくにつれて円柱後方 に双子渦が発達してゆく様子がよくわかる.

このようにして定常解を求めた後, 質量のない仮 想粒子を流速と同一の速度で動かすことにより流跡 を計算する，さらに，円柱表面での応力分布を計算 し, 円柱に働く流体力を得る.

$d=0.512 \mathrm{~mm}, l=30 \mathrm{~mm}$ のピアノ線を $0.05 \mathrm{wt}$ \% PAA（ポリアクリルアミド）水溶液中で落下さ せたときの回転角 $\beta$ (線状体の軸が鉛直方向とな す角度で， $\beta=0^{\circ}$ は鉛直な姿勢を表わす）に対す るR および線状体重心の運動方向が軸方向となす 角度 $\alpha$ の変化を図 5 に示す。この場合, 線状体を

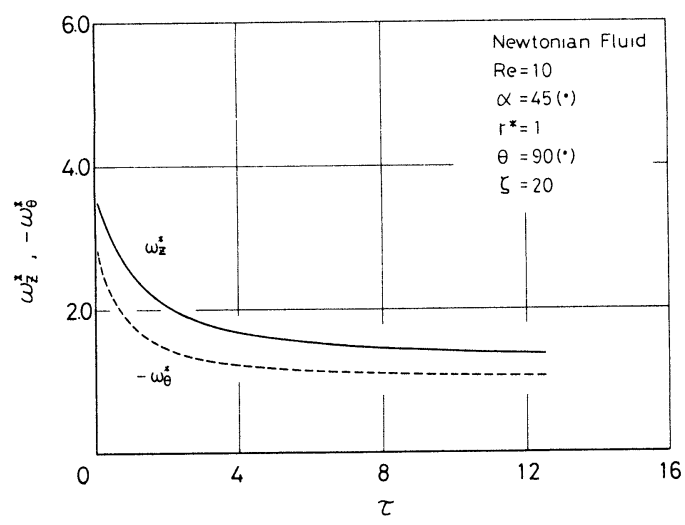

(a)

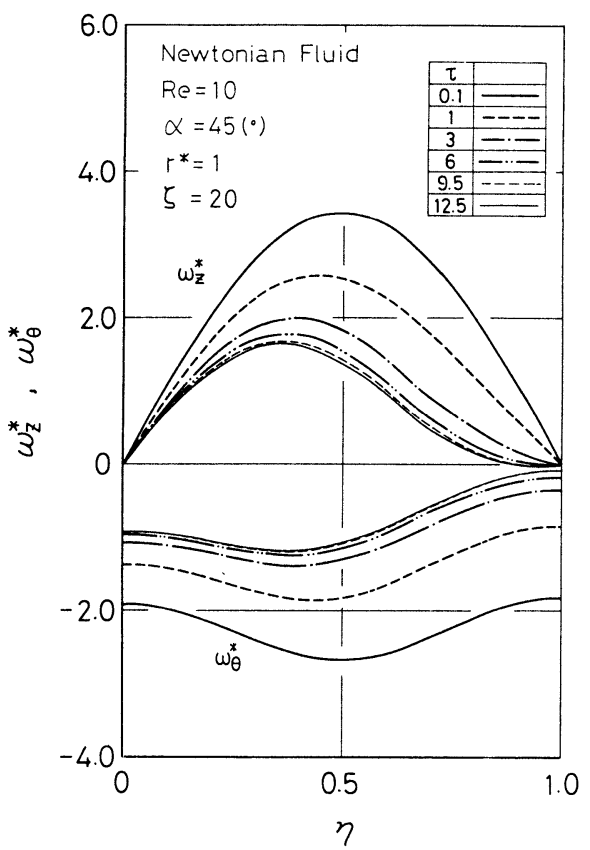

(b)

図 4 円柱表面の渦度の発達状態

である. 
水平に近い姿勢 $\beta \doteqdot 90^{\circ}$ から落下させると線状体 は鉛直な姿勢をとる向きに回転し, 角速度 $\dot{\beta}$ は $\beta$ $=55^{\circ}$ 程度まで加速される. そして, 線状体は $\beta$ $=21^{\circ}$ 程度まで回転した後その姿勢を保ったまま並 進運動する．また， Reは高々10程度である.

そこで，表 1 に示すように，数值計算においても $R_{e} \leqq 10$ とし, 円柱の傾斜角度 $\alpha$ を変えるととも

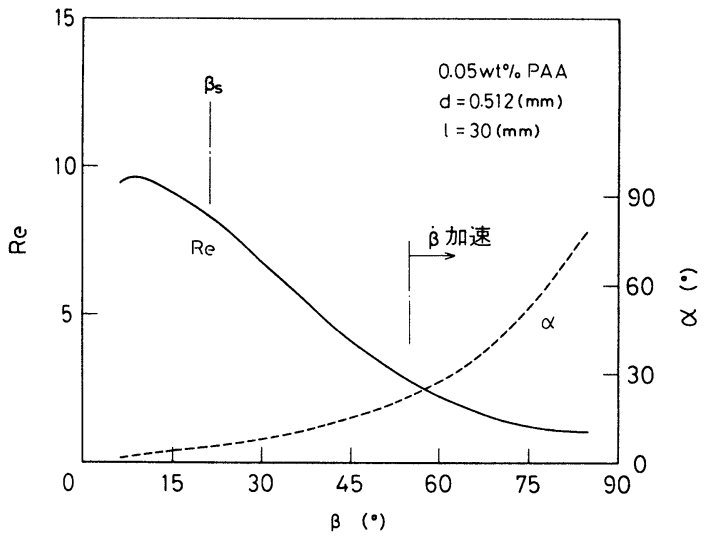

図 5 線状体の運動特性

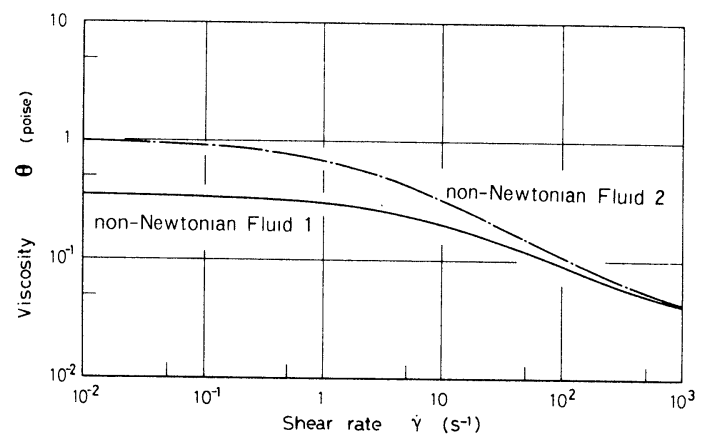

図 6 計算に用いた非ニュートン流体の流動特性
に非ニュートン流体の場合直径 $d$ を変化させた。な お， 2 種類の非ニュートン流体の流動曲線は図 6 に 示す通りである.

数值計算に用いた有限差分メッシュは， $0 \leqq$ $\eta \leqq 1$ で $\Delta \eta=1 / 12,-1.0 \leqq \xi \leqq 1.2$ で $\Delta \xi=0.1$, $-20 \leqq \zeta \leqq 60$ で $\Delta \zeta=2.5$ であり, 無限遠方の位 置は $\gamma_{\infty}^{*}=43.4$, 軸方向には円柱端面から20の距 離である。

初期条件は, ニュートン流体の場合一様流れとし, 非ニュートン流体の場合には，ニュートン流体の定 常解とする.

\section{3. 流れの可視化実験}

実験装置の概要を図.7に示す．流体は貯水タンク (9)からポンプ110よりヘッド タンク(1)へ送られる. ヘッドタンク内ではオーバ フローにより位置水頭 が一定に保たれる、ヘッドタンクを出た流体はフ ロート式流量計(3)を通り整流部(5)へ入る. 整流部に は縦および横方向の整流格子(17)と金網(16)が設けてあ る.ノズル部(6)を経た流れはほぼ一様となり可視化 実験を行うテスト部77へ入る。テスト部の上面には 幅 $5 \mathrm{~mm}$, 長さ $210 \mathrm{~mm}$ のスリットが設けてあり, ここから流路内に円柱を入れる。 そして, 実験の際 にはスリットを塞いでおく。

図 8 に実験に用いた円柱の形状と可視化装置の詳 細を示す. 円柱は $d=5 \mathrm{~mm}, l=200 \mathrm{~mm}$ で, 0.5 $\mathrm{mm}$ の穴が端面の中心および円筒上 $5 \mathrm{~mm}$ 間隔で設 けてあり，この穴からメチレンブルー溶液を低速 度で流出させ, 円柱周辺の流れ模様をテスト部の上 方から撮影する.

使用した流体は水およびポリアクリルアミド

表 1 計算条件

\begin{tabular}{|c|c|c|c|c|c|c|}
\hline fluid & & $R_{e}$ & $\alpha\left(^{\circ}\right)$ & $d(\mathrm{~mm})$ & $l^{*}$ & $\Delta \tau$ \\
\hline \multicolumn{2}{|l|}{ Newtonian } & $\begin{array}{l}0.1 \\
1 \\
10 \\
10 \\
10\end{array}$ & $\begin{array}{l}45 \\
15 \\
75\end{array}$ & 5 & 40 & $\begin{array}{l}0.5 \times 10^{-4} \\
0.5 \times 10^{-3} \\
0.5 \times 10^{-2} \\
0.5 \times 10^{-2}\end{array}$ \\
\hline \multirow{3}{*}{$\begin{array}{l}\text { non- } \\
\text { Newtonian }\end{array}$} & \multirow{3}{*}{1} & $\begin{array}{l}1 \\
10 \\
\end{array}$ & 45 & 5 & \multirow{3}{*}{40} & $\begin{array}{l}0.5 \times 10^{-3} \\
0.5 \times 10^{-2}\end{array}$ \\
\hline & & $\begin{array}{l}1 \\
10 \\
\end{array}$ & 45 & 2 & & $\begin{array}{l}0.5 \times 10^{-3} \\
0.5 \times 10^{-2}\end{array}$ \\
\hline & & 1 & $\begin{array}{l}15 \\
75 \\
\end{array}$ & 2 & & $0.5 \times 10^{-3}$ \\
\hline $\begin{array}{l}\text { non- } \\
\text { Newtonian }\end{array}$ & 2 & 1 & 75 & 2 & 40 & $0.5 \times 10^{-3}$ \\
\hline
\end{tabular}

non-Newtonian $1: \eta_{0}=0.3527$ (poise), $\eta_{\infty}=0.0256$ (poise), $x=0.1871$

non-Newtonian $2: \eta_{0}=1.005$ (poise), $\eta_{\infty}=0.0240$ (poise), $x=0.4914$ 


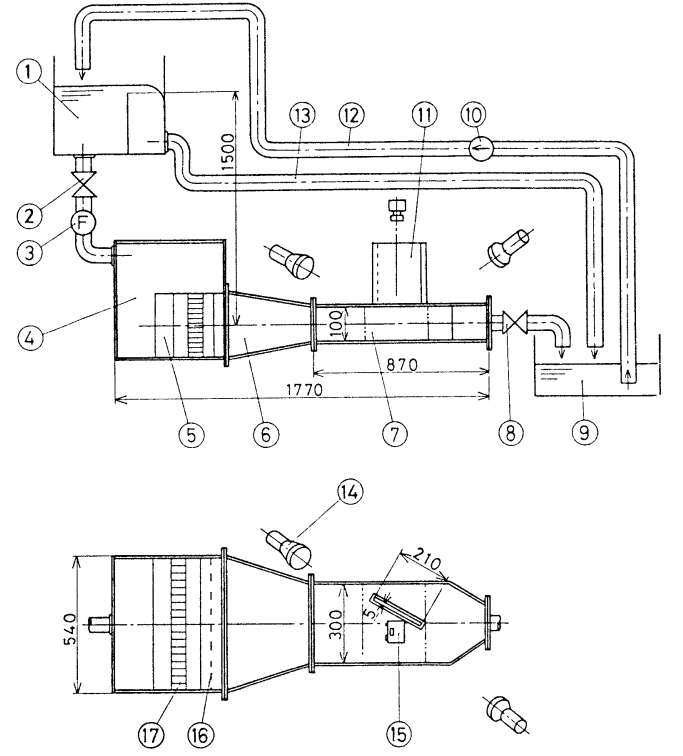

(1)ヘッドタンク (2)流量調節用バルブ

(3)フロート式流量計 (4)リザーバー

(5)整流部 (6)ノズル部 (7)テスト部

(8)流量調節用バルブ (9)貯水タンク

(10)ポンプ (11)円柱固定部分 (12)循環用パイプ (13)排水用パイプ (14)光源 (15)カメラ (16)金網 (17)整流格子

図 7 流れの可視化実験装置概要

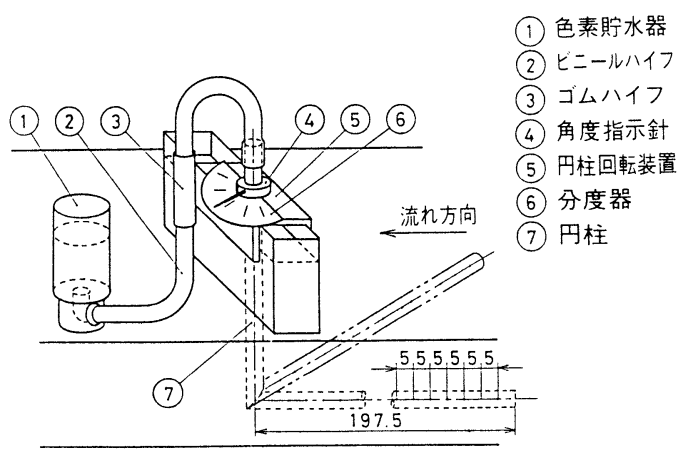

(a)

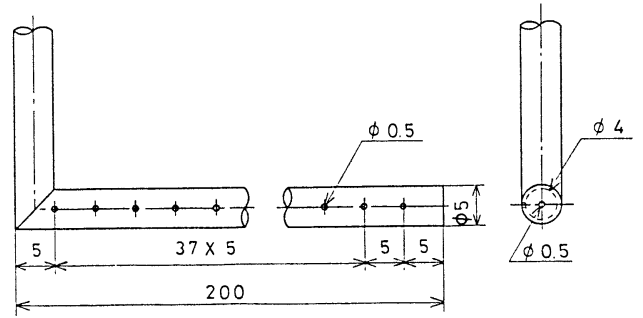

(b)

図 8 可視化装置の詳細と円柱形状

(PAA; Separan AP-30, Dow Chemical 社製造) の $0.05,0.1 \mathrm{wt} \%$ 水溶液である。これらの溶液は ポンプで輸送しているため，長時間にわたって使用
すると, 劣化し図 9 に示すように流動特性が変化す る。そこで，同じ溶液を 4 時間程度使用した後には 新しい溶液を用いるようにした。なお, 図中の曲線 は Cross モデルから求めたものである.

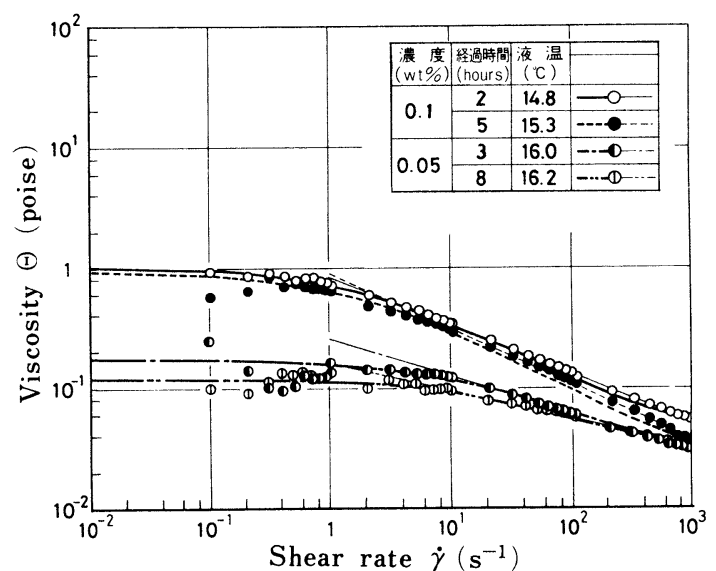

図 9 可視化実験に用いたPAA 水溶液の流動特性

\section{4. 円柱回りの流跡}

円柱の回り23か所の初期位置(流跡の図において, 1 から23の番号が付けてある) から仮想粒子を動か すことによって得られる流跡は 3 次元の曲線にな る.そこで, 流跡は流れの対称面 $(\theta=0, \pi)$ お よび $\gamma^{*} \theta$ 面への正射影で表わすことにする．ここ では, 流れの可視化実験結果と数值解析結果を比較 するために，流跡は主に流れの対称面への正射影で 示してある。

図10に $\alpha=15^{\circ}, 45^{\circ}, 75^{\circ}$ の場合のニュートン流 体の流跡を示す. 図10 $\left(\mathrm{a}_{1}\right) \sim\left(\mathrm{a}_{3}\right)$ は, $\gamma^{*}{ }_{0}=1.8, \theta_{0}$ $=5^{\circ}$ の初期位置から仮想粒子を動かしたときの数 值解析結果であり, 図 $10\left(b_{1}\right) \sim\left(b_{3}\right)$ は水の可視化実 験結果で $R_{e}=9.7$ である.

ニュートン流体と非ニュートン流体 1 の流跡を比 較した図11(a)を見るとわかるように，流跡が円柱に 近づくにつれて非ニュートン流体の方が流跡の方向 が近寄り流れの方向に近くなる。すなわち, 流体が 円柱近傍で軸方向に流れやすい，これは，非ニュー トン流体の場合円柱近傍に粘度の低い領域が存在す るためであると考えられる.

図10，11の数値解析結果と可視化実験結果を比較 すると, 実験では，色素が円柱後方に回り込んだ後， 円柱から離れる際円柱軸方向に鋭く立上がる現象が 見られるのに対し，数值解析結果では見られない。 これは, 実験では色素が円柱後方に生じている双子 渦の領域に入るが, 数值解析では仮想粒子が渦の上 方を通過するためである. 


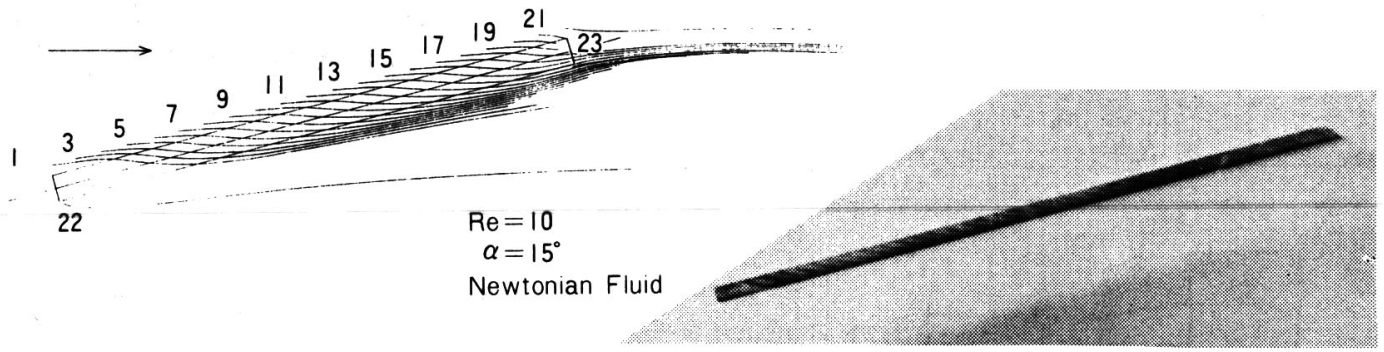

$\left(a_{1}\right)$

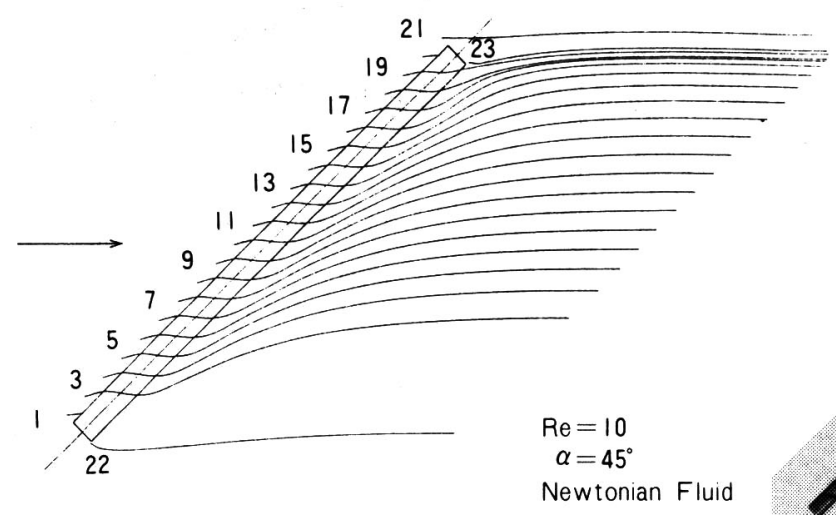

$\left(b_{1}\right)$

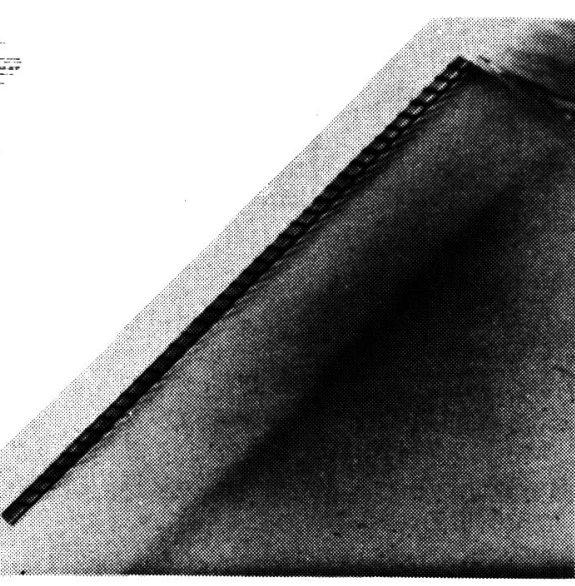

$\left(b_{2}\right)$

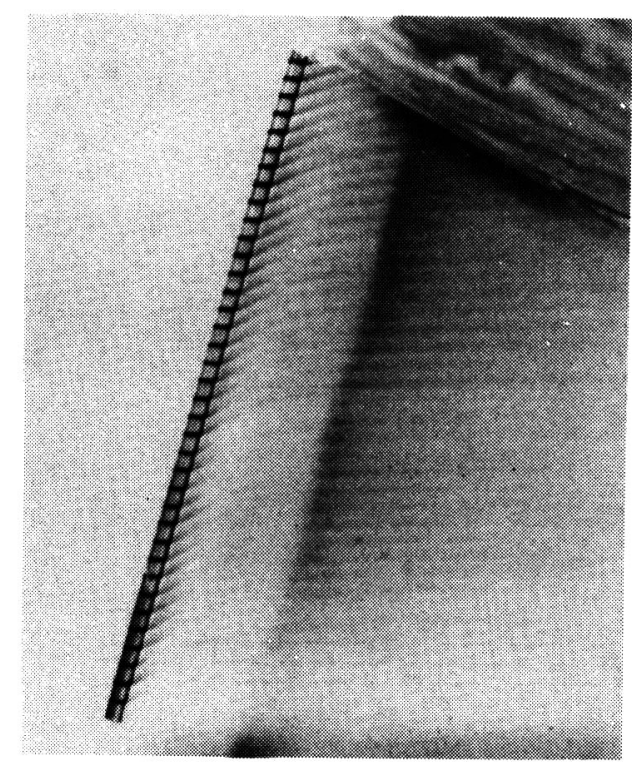

$\left(\mathrm{a}_{3}\right)$

$\left(b_{3}\right)$

図10 円柱回りの流跡

(a)数値解析結果 $\gamma_{0}{ }^{*}=1.8, \theta_{0}=5^{\circ}$

(b)水の可視化実験結果 $R_{t}=9.7$ 


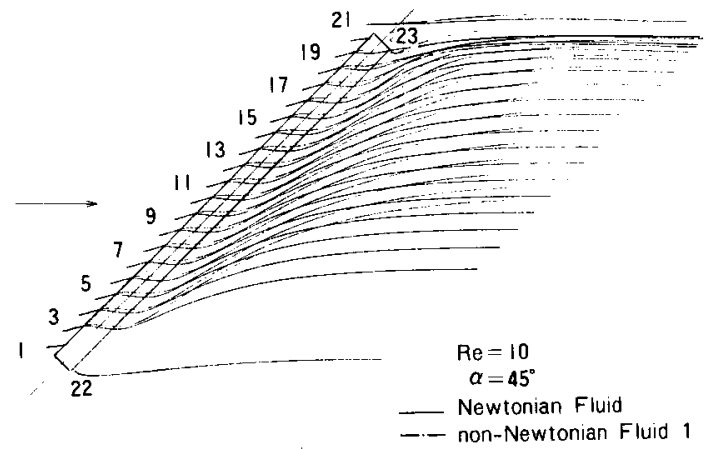

(a) $r_{0}^{*}=2.0, \theta_{0}=5^{\circ}$

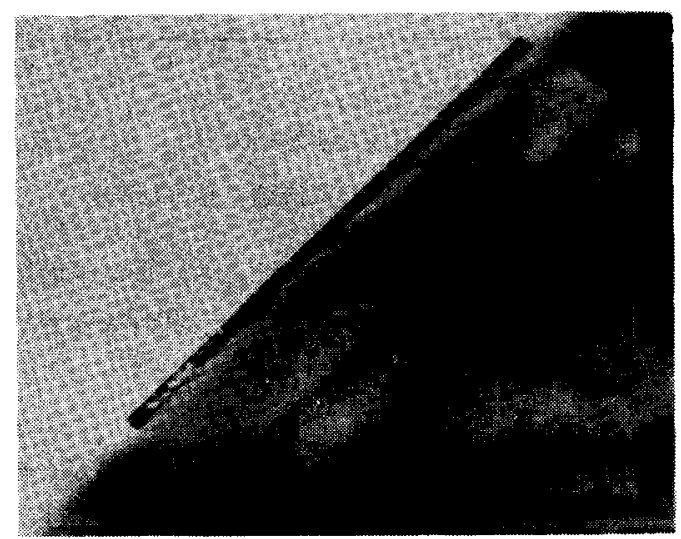

(b) $0.05 w t \% \mathrm{PAA}, \mathrm{Re}=10$

図11 円柱回りの流跡

(a)数值解析結果, (b)可視化実験結果

そこで，仮想粒子の初期位置を双子渦に近づけ $\left(\gamma_{0}{ }^{*}=1.1, \theta_{0}=135^{\circ}\right)$, 渦中での流跡を調べる. 図12，13はそれぞれ $d=5 \mathrm{~mm}$ および $d=2 \mathrm{~mm}$ の場合の流跡である. 図12(a)，13(a)から，粒子は渦

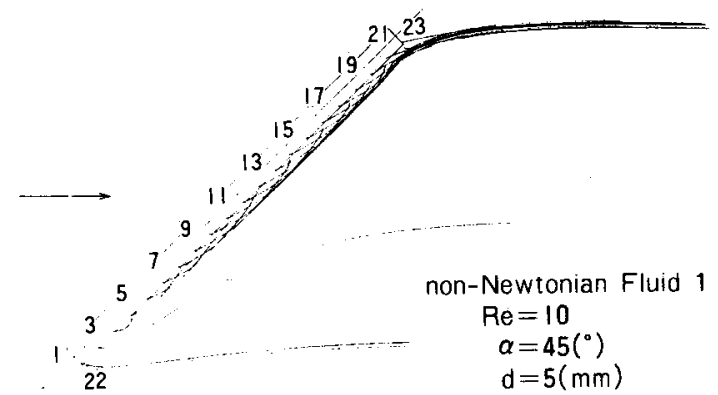

(a)

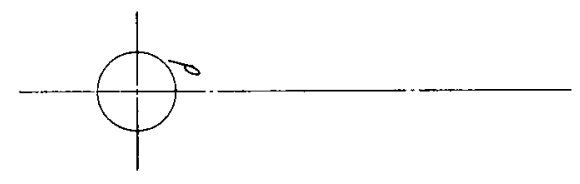

(b)

図12 渦中における流跡 $d=5 \mathrm{~mm}, \gamma^{*}=1.1, \quad \theta_{0}=135^{\circ}$

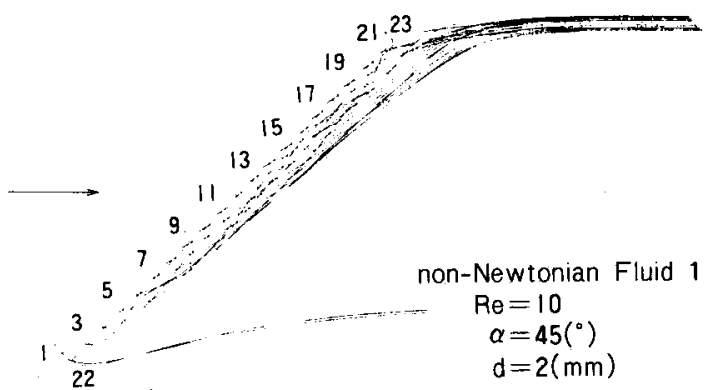

(a)

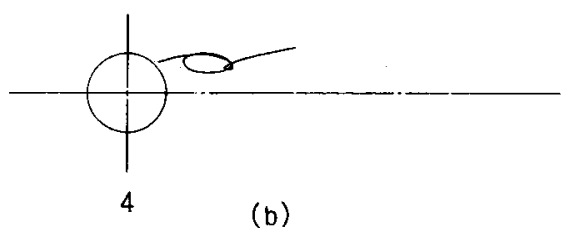

図13 渦中における流跡 $d=2 \mathrm{~mm}, \gamma^{*}=1.1, \theta_{0}=135^{\circ}$

によって回転させられながら円柱軸方向へ移動する のが見られる。また，実験で観察された円柱から離 れる際の流跡の鋭い立上がりが見られる。さらに， 渦中での流跡から円柱後方に生じている渦の長さが ほぼ推定でき，円柱の直径が小さい方が渦の長さは 大きくなることがわかる. 図12(b)，13(b)には，4 番 目の初期位置 $\left(\gamma_{0}{ }^{*}=1.1, \theta_{0}=135^{\circ}, \zeta_{0}=6\right)$ か ら粒子を動かしたときの流跡の $\gamma^{*} \theta$ 面への正射影 を示す.

非ニュートン流体の場合の方が円柱近傍で軸方向 に沿って流れすいと述べたが,これはつぎのように 定義される角度 $\Delta \alpha$ を調べることにより明確にな る.

図14に示すように, $\theta=90^{\circ}$ での流跡の方向が近 奇り速度となす角度を $\Delta \alpha$ とする。ただし，時計 回りを正にとる.

図15(a)，(b)に示す数値解析結果は, $\xi=0.1\left(\gamma^{*}\right.$ $=1.37), \theta=90^{\circ}$ の格子点での $v_{\theta}^{*}$ ， $v_{z}^{*}$ の値を用 いて求めたものである. 数値解析結果之図15(c)の実 験結果を比較すると, 数值的には異なるが, ニュー トン流体の場合 $\alpha=75^{\circ}$ の場合の方が $\alpha=45^{\circ}$ の ときより $\Delta \alpha$ が小さくなること，および非ニュー トン流体の場合の方が $\Delta a$ が小さくなることなよ゙ 数值解析結果亡実験結果は, その傾向が一致してい ることがわかる。

また, 図15(b)より $R e$ が同一の場合, 直径が小さ い場合の方が流体は円柱軸方向に流れやすいことが わかる．特にReが大きい場合，この傾向が著しい， これは，(11)式から同一のR，の場合， $d$ 小゙さい方 が $4\left|I_{\bullet}\right|$ の値が大きくなり,従って, 円柱近傍で粘 
48

度の低下が大になるためであると考えられる，さら に, 同図には $R_{e}=1, \alpha=75^{\circ}, d=2 \mathrm{~mm}$, 非 ニュートン流体 2 の結果は記載されていないが， の値全体にわたって非ニュートン流体 1 の場合より

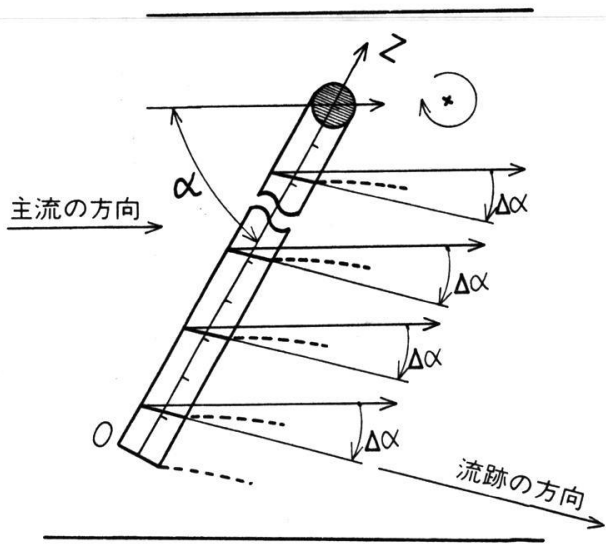

図14 $\Delta \alpha$ の定義

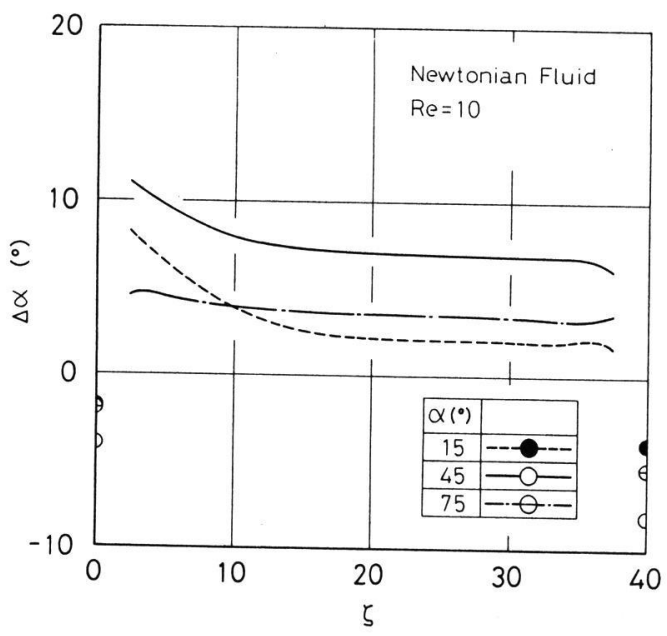

(a) 数值解析結果, ニュートン流体

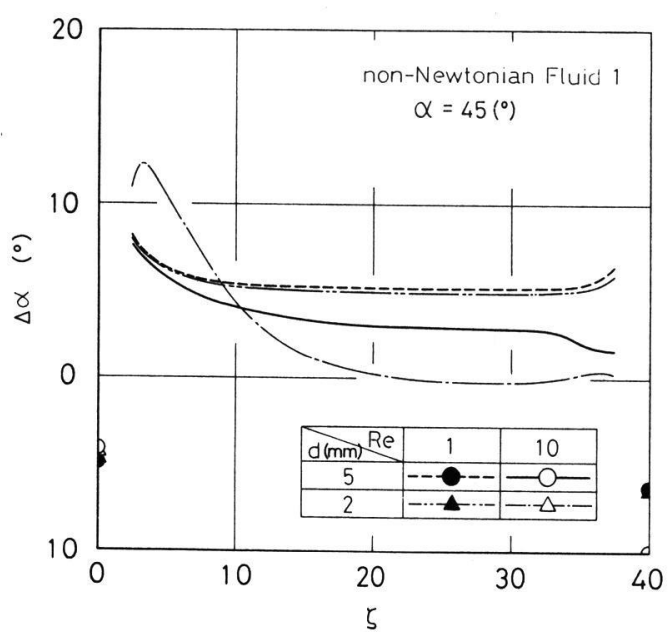

(b) 数值解析結果, 非ニュートン流体
瀻維機械学会誌

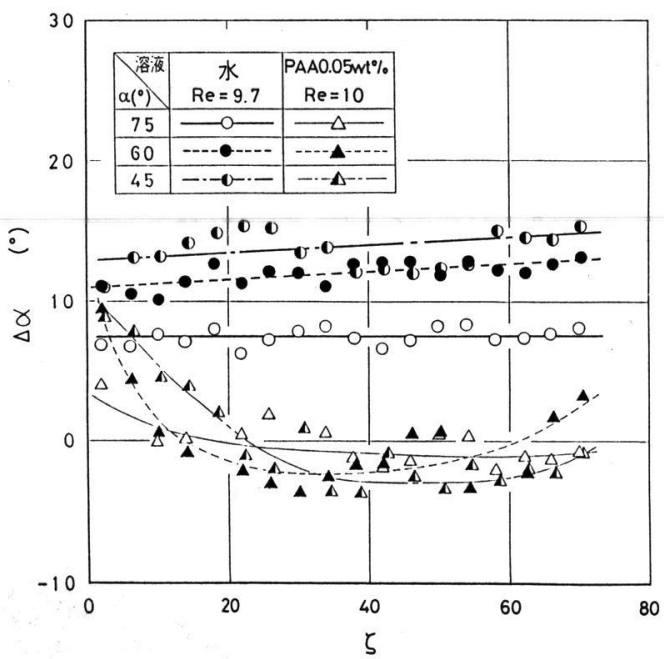

(c) 可視化実験結果

図15 円柱近傍における流跡の方向の評価

$0.1 \sim 0.2$ 程度 $\Delta \alpha$ の值が小さくなるだけである. これは, 非ニュートン流体 2 の場合, 円柱近傍で粘 度は大きく低下するが，それに伴ない $v^{*}$ が $v_{z}^{*}$ と 同じ程度に増大した結果である。

なお，図15(a)，(b)から分かるように $\Delta \alpha$ は 0,40 近くで極值をもつが, 格子間隔が $\Delta \zeta=2.5$ であるため, $\Delta \alpha$ の極值とそのときの $\zeta の$ 值が求ま らないので, 曲線は $2.5 \leqq \zeta \leqq 37.5 の$ 範囲で描

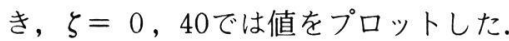

以上の上うに,数値解析結果と可視化実験結果は, 流跡の傾向がよく一致しており, このことは, ここ で用いた計算方法で傾斜円柱周辺の流れ場を表現で きることを示している.

\section{5. 円柱回りの流速分布}

図16に $\zeta=20$ の $\gamma^{*} \theta$ 面内における流速分布を示 す。なお，流速べクトルの矢印は，その起点が流速 $\stackrel{1}{\rightarrow}$

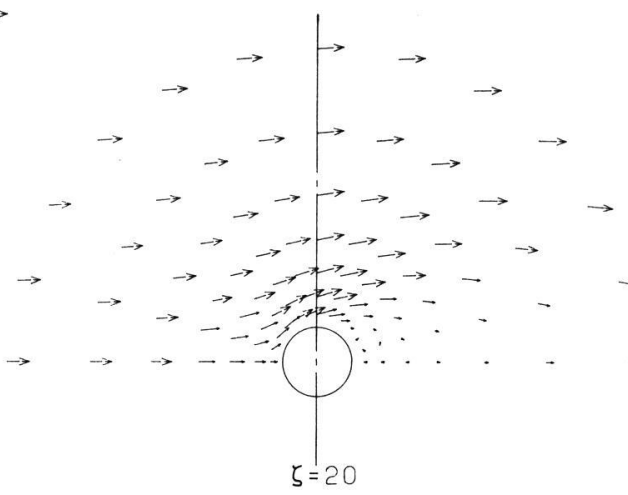

(a)非ニュートン流体 $1, \alpha=45^{\circ}, d=5 \mathrm{~mm}$ 


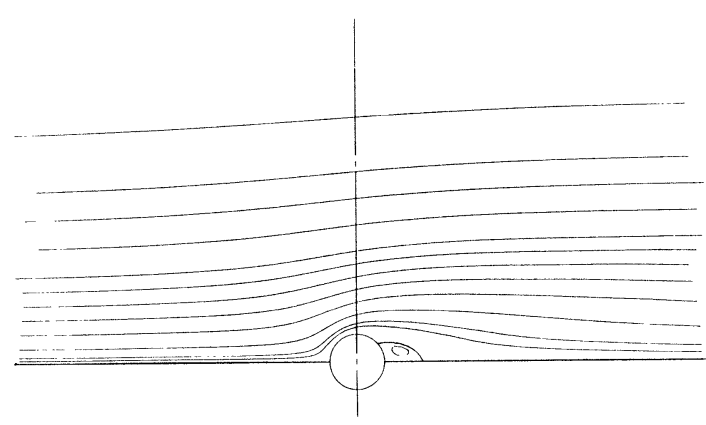

(b) 非ニュートン流体 $1, \alpha=90^{\circ}, d=5 \mathrm{~mm}$

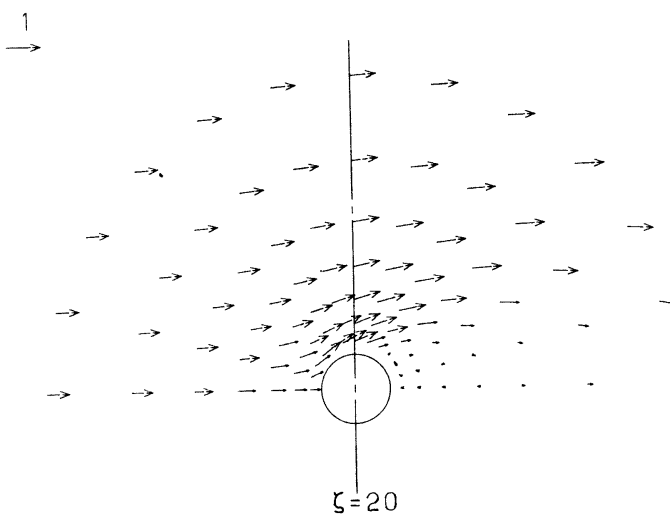

(c) 非ニュートン流体 $1, \alpha=45^{\circ}, d=2 \mathrm{~mm}$

$\stackrel{1}{\rightarrow}$

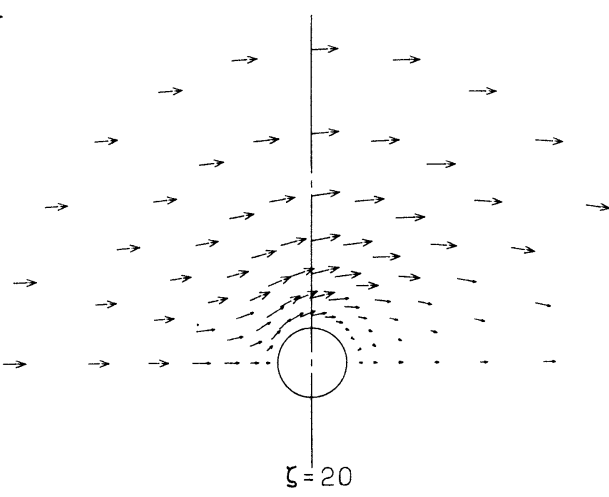

(d) ニュートン流体, $\quad \alpha=45^{\circ}$

図16 $\gamma^{*} \theta$ 面内の流速分布, $R_{\mathrm{e}}=10$

表示の位置を表わしている，また，図16(b)には，参 考のために非二ュートン流体 1 の一様流れ中に直角 におかれた無限長円柱回りの流線を示している.

円柱表面に沿って発達している境界層の剥離に は, 円柱近傍の局所レイノルズ数が関係すると考え られる. 円柱近傍の粘度は, ニュートン流体 $(d)$, 非ニュートン流体 1 で $d=5 \mathrm{~mm}(a)$, 非ニュート ン流体 1 で $d=2 \mathrm{~mm}(c)$ の順に小さくなるので, 局所レイノズル数は逆にこの順に大きくなる．従っ
て, 円柱後方の双子渦の大きさは $(d),(a),(c)$ の 順に大きくなる.

図17には, $\gamma^{*}=1.37$ の筒面内における流速分

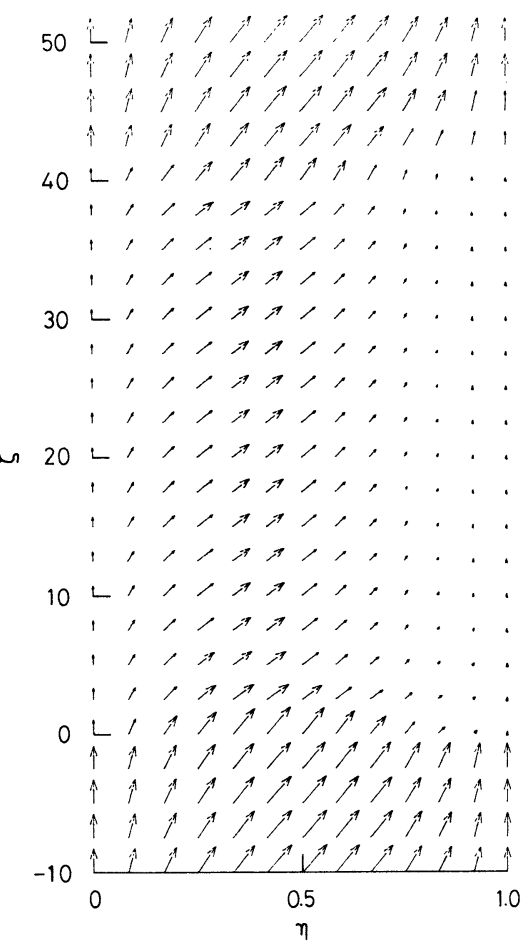

(a) $\alpha=45^{\circ}$

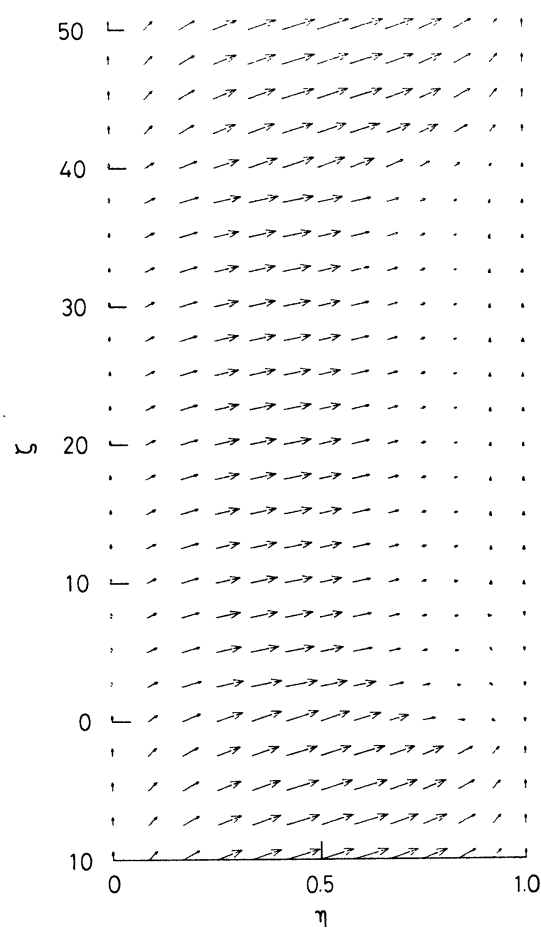

(b) $\alpha=75^{\circ}$

図17 $\gamma^{*}=1.37$ 面内の流速分布, 二ュートン流体, $R_{e}=10$ 
布が図示してある， $\alpha=45^{\circ}$ の場合には見られない が, $\alpha=75^{\circ}$ の場合, $\eta=1\left(\theta=180^{\circ}\right)$ 付近の 0 $<\zeta<8$ 程度の領域で鋭いかだを回る流れのため逆 流が生じていることがわかる.

\section{6. 結}

本報では，一様流れ中に傾けておかれた有限長円 柱周辺の流れ状態を, Cross モデルを用いて数值解 析により求め, 流体のもつ非ニュートン粘性 (shear thinning viscosity）が流れに及ぼす影響を明らか にした。また，流れの可視化実験から得られた結果 之数值解析結果を比較し, 数值解析の妥当性を検討 した.

その結果, 流跡は円柱後方に回り込んだ後, 円柱 から離れる際円柱軸方向に鋭く立上がること，およ び非ニュートン流体の場合の方が円柱近傍で軸方向 に沿って流れやすいことが明らかになった。この傾 向は, 流れの可視化実験から得られた結果之一致し ている．従って，ここで用いた計算方法は傾斜円柱 周辺の流れを表現するのに有効である.

また，数值解析から，非二ュートン流体の場合 Reのみならず円柱の直径が円柱後方に生ずる渦の 長さに影響を与え，直径が小さい場合の方が渦の長 さは大きくなることがわかった。

\section{参考文献}

1）堀川, 千葉ほか; 䋞機論文集，33，T 118 (1980)

2) K. Chiba and A. Horikawa ; Proc., II , 8 th Australasion Fluid Mech. Conf., 13B, 9 (1983)
3) 中村, 千葉ほか: 繊維.工学, 36, P 451 (1983)

4) A. Thom : Aero. Res. Counc. R. \& M., no. 1194 (1928)

5) F. T. Smith : J. Fluid Mech., 92, 171 (1979)

6) B. Fornberg ; J. Fluid Mech., 98, 819 (1980)

7) J. S. Ultman and M. M. Denn : Trans. Soc. Rheol., 14, $307(1970)$

8) D. F. James and A. J. Acosta ; J. Fluid Mech., 42, 269 (1970)

9) R. A. Mashelkar and G. Marrucci ; Rheol. Acta, 19, 426 (1980)

10) A. Slaouti and J. H. Gerrard ; J. Fluid Mech., 112, 297 (1981)

11) S. E. Ramberg : J. Fluid Mech., 128, 81 (1983)

12) M. M. Cross ; J. Coll. Sci., 20, 417 (1965)

\section{（付録）}

本報で使用したPAA 水溶液も含めて一般に高分子溶液は, Shear thinning 特性ばかりでなく弾性的性質も有している。 ここでは, Shear thinning 特性が流れに与える影響を調べた が，弾性的性質の影響は今後の研究課題として残されている. 粘弾性流体の円柱周辺の流れ（および流体力）を調べる手 段の1つとしてつぎの方法が考えられる.

構成式は，上対流微分 Do/Dtを用いた Maxwell モデルの粘 度を(10)式で示すCross モデルで変化させた式

$\left(1+\lambda D_{0} / D_{t}\right) T^{i j}=2 \Theta e^{i j}$ (19)

とする.ここで, $\lambda$ は緩和時問である.

対象にする流体は，粘性的性質にわずかに弾性的性質が含ま れている流体であるので, ワイセンベルグ数 $W_{e}=\lambda U_{\infty} / 2 a$ が 1 より小さいよいう仅定が導入できる.

そこで, 流速, 応力, ベクトル ポテンシャル，渦度および粘 度をW.のべき級数で展開し， $W_{e} 0$ 次，1 次および 2 次の項に対 忘する渦度移動方程式, $\boldsymbol{\phi}^{*}$ と $\boldsymbol{\omega}$ *の関係を表わす式, 境界条 件を導く.こして, 冬次数における基礎式を数值解析により解き, W、のべき級数の形で加え合せれば，粘弾性流体の流れ場が得ら れる.この場合, 本報で求めた解はWe 0 次の解となる. 